Indonesian Journal of EFL and Linguistics

Vol. 5 No. 2, 2020

eISSN: 2503-4197, pISSN: 2527-5070

www. indonesian-efl-journal.org

\title{
Teachers' Questions in Elementary School English Learning: Types and Functions
}

\author{
Naomi Dwi Aprina \\ Yogyakarta State University, Indonesia \\ e-mail: naomi.dwiapriana@gmail.com \\ Erna Andriyanti \\ Yogyakarta State University, Indonesia \\ e-mail: erna.andriyanti@uny.ac.id
}

\begin{abstract}
:
Question types usually used in classroom learning are display questions and referential questions. Many teachers mostly used display questions in their classroom learning. However, studies showed that display questions limit the students' opportunity to produce the language. Therefore, this present study aimed to analyse the contribution of teacher questions' types in English classroom learning to classroom interaction. The participants of this qualitative study were three sixth grade English teachers from three different Islamic schools in Yogyakarta. The data were collected through classroom observation. The result shows that the teachers used both display and referential questions, and all teachers used display questions more frequently. Furthermore, the result of the analysis shows that referential questions received longer responses than display questions. It also indicated that referential questions gave the students more opportunities to practice the language. However, both display questions and referential questions are important for EFL students. The use of both question types can be adjusted based on the levels of the students, the purpose of the lesson and students' learning strategies.
\end{abstract}

Keywords: elementary students, interaction, teacher questions

Indonesian Journal of EFL and Linguistics, 5(2), 2020 
Naomi Dwi Aprina, Erna Andriyanti

\section{INTRODUCTION}

Many studies such as from Al-zahrani \& Albargi (2017), Mulyati (2013) and Cynthia (1986) find out the roles of teacher questioning in English classroom learning. In general, a teacher question is delivered for several purposes of checking the students' understanding (Nunan \& Lamb,1996), engaging the students with the lesson, attracting the students' interest, creating students' critical thinking (Milawati \& Suryati, 2019), and creating interaction. Therefore, the role of teacher questions is fundamental in classroom learning.

Asking a question as part of classroom activities in English classrooms is especially important because of its role in classroom interaction. Teacher questions can help the students involve themselves with the language and produce the language. Nevertheless, a question might open up or shut down students' participation in the classroom (Boyd, 2015). Considering its positive and negative sides, a teacher should be able to maximize the use of questions to promote effective classroom learning.

According to Long and Sato (1983), there are two types of questions: display and referential questions. Both types of questions are important for a language teacher. Display questions are used for factual information meanwhile referential questions a re used for evaluation, opinion or interpretation (Brook, 1986). Meanwhile, according to Blosser, (1975), there are 4 types of questions; managerial, rhetorical, close, and open. Managerial questions are used to maintain the classroom condition, rhetorical questions are used to emphasize the idea in the lesson, close questions are used to check and focus on particular statement and open questions are used to create interaction. However, in this present study, the researcher only uses Long and Sato (1983) question types as the basic theory in analyzing the data. Long \& Sato (1983) classification of questions shows how interaction can be generated in the classroom so it is most suitable to be used for the study.

Similar research on discourse analysis of teacher questions (Omari, 2018; Affandi, 2016; Yunita 2016) discovered that types of teacher questions used in the classroom influence students' response. According to Cynthia (1986), referential question is good to be used in classroom learning because it is similar to the students' everyday conversation. It means referential questions can promote more interaction in the classroom. However, Wright, (2016) and Shomoosshi (2004) found out that in the classroom display questions are mostly used by the teacher than referential questions. Furthermore, when the teacher delivers display questions, the students' response is limited and the opportunity in producing the language is lessened.

Many studies on discourse analysis such as Rachmawaty \& Ariani (2018), Yusriati \& Tarigan (2019), Erianti, Akib, \& Baso (2018) and Susantara \& Myartawan (2020) investigated the influence of questions types on the students' participation in the classroom learning in Senior high school and Junior high school level. There are still small studies which observe the influence of question types towards classroom learning of elementary school. In Indonesian contexts, English is not necessarily a 
compulsory subjects, therefore many schools especially public school have not yet include English in their teaching and learning process. Therefore, the current study seeks to find the questioning activities in non-public elementary school. The selected participants which were coincidently private Islamic school produced their own English text books. This condition is used as a consideration for English language learning practice with regard a different result with general English learning practice in elementary school.

In response to the background before mentioned this study tries to display the composition of teacher question types used in the classroom and also explain which question types can promote and engage the students more in classroom interaction. By understanding the role of teacher questions towards classroom interaction, a teacher can maximize the use of teacher questions and create an ideal composition of teacher questions which best promotes classroom interaction by looking at the students' response. To conclude, this study aims to find out what types of questions is used by the teacher during classroom practice and also to find out what response is elicited by the teachers' questions types.

\section{LITERATURE REVIEW}

\subsection{Asking Questions}

In a classroom teaching and learning process, the teacher has a responsibility to transfer the knowledge, manage the classroom, and relate the material with the students' background knowledge. The way the teacher fulfills their duty is different from each other. The teacher uses their talk to deliver the material, ask the students to do some activities, control the students, and check their understanding. According to Flowerdew (2013) conversation includes asking, answering, disagreeing, offering, contesting, requesting, teasing, finessing, complying, performing, noticing, promising, and so forth. To add based on Foreign Language Interaction (FLINT) system in Brown (2001), classroom interaction might give direct influence (giving information, direction, critics) and indirect influence (affective, praise/encouragement, exploration to the students' idea, and asking a question). In this current study, the researcher limits the focus on the conversation which includes the teacher talk in asking a question.

Questions and answer activity is an activity which happens almost in every classroom activity. Usually, the teacher asks the students to check their understanding of the material that had been learned, Nunan \& Lamb (1996). After delivering the material in the classroom, the teacher often tries to figure out whether or not the students share the same understanding with the teacher. This use of asking questions sometimes also functions to evaluate the previous material or to correlate to the next material.

As mentioned previously, a teacher should be able to use his/her speech as effective as possible to create a meaningful interaction. Another use of asking a question is to initiate a classroom interaction (Ellis, 1992; Nunan \& Lamb, 1996; Brown \&Wrag, 1993). When the teacher gives the students a question, the teacher expects a response whether it is in the form of an answer or question. When the students answer the 
questions, the teacher will give feedback, and if it is impossible the other students will ask the following questions so the effective communication/interaction will be achieved. Besides, a question is sometimes also useful for focusing the students on certain topics or issues (Brown \& Wragg, 1993). To conclude, a teacher uses a question to facilitate the learning process.

\subsection{Question Types}

Questioning has been a topic in education field. Many experts have different opinions on question types' classification. According to Wragg (1993) in Brown \& Wragg (2001), question types consist of three: Managerial types, Information or data, and Higher-order. Richards \& Lockhart (1996) also divide question types into three: Procedural, Convergent and Divergent. However, Long \& Sato (1993) and Darn (2008) mentioned two types of questions that are display and referential. This current study uses the types of asking a question from Long \& Sato (1983) and Darn (2000) as a basic theory in analyzing and presenting the data.

Many studies show that display question is mostly asked by the teacher in the classroom learning than referential question (Erlinda \& Dewi, 2014; Fitriani \& Amilia, 2017). Display and referential questions have a different response from the students since both questions type involved different knowledge from the students.

According to Nunan (1989), display question is a question where the one who asks the question (teacher) knows the answer. This definition is related to the question definition as tools for checking the students' understanding. This type of question involves memorizing the process to answer the questions. In the same vein, Ellis (1992) defines display questions as a tool to test an addressee about a particular /linguistic topic correctly. Display question is not suggested to enrich the classroom interaction because it generates different language features from the daily discourse.

In contrast, referential question is a type of question in which the people who give the question do not always know the answer (Nunan, 1989). To add, Ellis (1992) defines it as a tool for finding the information. This type of question involves the students' background knowledge and understanding toward a certain topic/issue. This type of question is good to initiate a longer interaction in the classroom. While answering the referential question, unconsciously the students are relating their understanding toward the topic with their background knowledge. Since it deals with the students' background knowledge, the teacher does not necessarily know the exact answer for his/her questions. This type of question nearly resembles the language learners experience outside the classroom. It is suggested to be used to trigger the classroom interaction.

As above mentioned, this current study is used question types from Long and Sato (1983) as the reference in interpreting the data gathered. This decision is made based on the definition of the question's types and its correlation with students' response. 
Therefore, it is assumed that Long and Sato (1983) is suitable to be used in analyzing and interpreting the data.

\subsection{The Impacts Questioning Activity to Classroom Interaction}

Classroom interaction is an essential factor to create an effective language learning process. The interaction in the classroom is done by the teacher and students. The teacher as a classroom director has a responsibility to produce a quality talking which can engage the students to communicate effectively. Incecay (2010) mentioned the type of teacher talk can determine the effectiveness of classroom learning. Therefore, the teacher should be able to create a situation where the teacher and the student's interaction is fruitful for students' language exposure.

Questioning is a part of learning activities. The selection of the question delivered in the classroom is adjusted with the purpose of the lesson. According to Cotton (2003); Brown \& Wragg (2001) questioning activity is good approach if the teacher can formulate a question that can promote creative thinking. Nashruddin and Ningtyas (2020) discovered the positive effect of questioning strategies in classroom interaction. As the core of language learning, interaction is correlated with how the teacher forms a question to prompt the interaction.

The purpose of the learning and the students' ability should be considered when forming a question. According to Boyd (2015), the students are likely talk less when they have to response a question related to critical response or some students tend to focus more in right answer and not about exploring ideas or opinion. In this case, questioning play as an important part to direct the students' interest to bring back the function of the teacher as a director of the interaction.

Interaction in the classroom does not only happen between teachers and students but also students and students. Teacher-student interaction is usually initiated and also ended by the teacher. This type of interaction commonly occurs when the teacher asks a question to the students/student and the students/student answer the question then the teacher gives the feedback. According to Al-zahrani \& Bargi (2017), teacher-student interaction follows the IRF (Initiate-Response-Feedback) pattern. The teacher holds the biggest talking time since they are the ones who controlled the interaction.

The next interaction is student-student interaction. This interaction can be expressed through pair work and group work. It also supports the student-centered approach because the student is the main character in the class. The students are the ones who initiate the interaction meanwhile the teachers' role is as a facilitator. Interacting with their peers will make the students more at ease using the language. They can start and end the interaction on their own. In contrast with teacher-student interaction, studentstudents interaction raises the possibility of higher student talking time. However, the teacher should be able to facilitate and manage the interaction that happens among the students still support language learning.

Indonesian Journal of EFL and Linguistics, 5(2), 2020 
As mentioned previously, questioning is the example of IRF interaction pattern. Boyd (2015) said in IRF pattern initiation play an important part in the success of the interaction. It means the question form is the key for the interaction. Questioning itself includes turn taking, time holding and uptake (Blackledge \& Creese, (2009); Gutierrez, (1993). Furthermore, to create more effective interaction the teacher should be able to give a feedback to the students' response so the students will experience more interaction over the first question.

This current study focuses on teacher-student interaction in the classroom. This decision is made based on the discourse analysis of question types. Furthermore, several features related to the interactive question measurement such as cognitive level and the complexity of the question was discussed.

\section{RESEARCH METHODOLOGY}

\subsection{Participants}

This descriptive study uses qualitative designs to get the actual condition or process that happens in the field. It tries to analyze the types of teacher questions within elementary classroom interactions. The participants of the study were three English teachers of sixth-grader Islamic Elementary School from three different schools in Yogyakarta, Indonesia. Rather than public schools, private Islamic schools were chosen as the subjects of the study. Private Islamic schools were chosen with regard to the implementation of English subjects and also the schools' vision and mission which see English as a requirement to become a global perspective Muslim. The average number of students in the classroom ranged from 24 to 32 students.

\subsection{Instrument}

The data were taken from classroom observation, which was done by analyzing 70 minutes of the long learning process. The data were adjusted for the readability of the result. The sample size is too small to generalize the influence of question types on the classroom interaction. The main focus of this study is to find out the questions types used by the teacher and its influence towards classroom interaction by looking from the students' response. Question types from Long and Sato (1983) was applied as a reference in analyzing and interpreting the data. Long and Sato (1983) concept of questions types is considered suitable for the current study with regards the students' response to teachers' questions and its' definition which describes classroom interaction.

\subsection{Data Analysis Procedure}

In analyzing the data gathered, the researcher following the step proposed by Miles, Hubermen \& Saldana (2014) which consist of data collection, data display, data condensation and drawing conclusion. After the researcher gathered the data, the researcher was transformed the data into a transcript. The next step was categorizing the data into three categories based on the reference used in the study. Therefore, the data were categorized into DQ (Display questions) and RQ (Referential questions). 
The data was simplified so the researcher can interpret the data easier. Next, the researcher drawing a conclusion based on the reference used in the study. The researcher also calculated the average number of words produce by the students. The result of the calculation is interpreted. The analyzing process was done and researcher concluded the findings.

\section{FINDINGS}

\subsection{Question Types}

The three participants share the same materials in the classroom practice however they have different ways in delivering the knowledge, so the total questions delivered in the classroom practice also different to each other. The material delivered in the classroom practice is local narrative texts. Specifically, Teacher A asked the students to translate the whole story together. As for T2, to give a better understanding of the story, the teacher played a video. Meanwhile, T3 asked the students to present the story.

The result of the analysis reveals that the total questions asked to students by the three teachers are: teacher A 38 questions, teacher B 15 questions and teacher C 48 questions. Table 1 visualizes the contribution of display and referential questions of each teacher. The range of question is from 11 to 32 questions for display questions and 3 to 18 questions for referential questions. Teacher A delivered the largest display question type meanwhile teacher $\mathrm{C}$ held the highest referential questions among the participant teachers. Aside from two types of questions propose by Long \& Sato (1983), the researcher also discovers the procedural question types in the classroom practice. Procedural question types is a type of questions which frequently asked by the teacher to open the classroom learning. Furthermore, this current study will only focus on the display and referential questions. The specification of the questions distribution is visualized in table1.

Table 1 Distribution of question types from three different teachers.

\begin{tabular}{llllll}
\hline \multirow{2}{*}{ No } & Teacher & \multicolumn{4}{c}{ Types of questions } \\
\cline { 3 - 5 }
\end{tabular}


All the teachers used both display questions and referential questions in the classroom. Table 1 illustrates that from the three teachers, all of them used more display question than referential questions. Display questions were delivered more than doubled in number of the total referential questions in the classroom of Teacher A and $\mathrm{B}$. The following are examples of both display and referential questions in the classroom.

The examples of display questions

Excerpt 1 Teacher A

T: Dari manakah cerita Malin Kundang berasal? Sumatera bagian mana? (Where is Malin Kundang story from? From which part of Sumatera?)

Excerpt 2 Teacher B

T: Apakah Malin kundang itu meniru seseorang? (Does Malin Kundang imitate someone?)

Excerpt 3 Teacher $\mathrm{C}$

T: Apa yang dikatakan Bandung Bondowoso saat mendengar persyaratan dari Roro Jonggrang? (What did Bandung Bondosowo say after hearing Roro Jonggrangs' condition?)

The examples of referential questions

Excerpt 4 Teacher A

$\mathrm{T}$ : What can we get from the story?

Excerpt 5 Teacher B

T: Apakah kelebihan Malin? (What are Malin's strengths?)

\section{Excerpt 6 Teacher $\mathrm{C}$}

T: What kind of attitudes that reflect durhaka pada orang tua? (What kind of attitudes that reflect rebellious attitude to parents'?)

\subsection{Classroom Interaction}

In this present study, the interaction in the classroom was measured by the total number of the words produced by the students in the classroom. Referring to the study of Qashoa (2013), the average words produced in the classroom was calculated by dividing the total words produced by the students with the total question from each type. Table 2 shows the average score of words produced from each type of question. From table 1.2 we can conclude that the average score of referential questions from the entire participant $(6.0,5.7$, and 4.7$)$ was higher than the average score of display questions $(2.5,1.3$, and 2.2$)$. 
Teachers' Questions in Elementary School English Learning

Table 2 The length of word produced (students' response) from each type of questions

\begin{tabular}{|c|c|c|c|c|c|c|c|}
\hline \multirow[t]{2}{*}{ No } & \multirow[t]{2}{*}{ Teacher } & \multicolumn{2}{|c|}{$\begin{array}{l}\text { The total words } \\
\text { produced by each } \\
\text { type of question }\end{array}$} & \multicolumn{2}{|c|}{ The total questions } & \multicolumn{2}{|c|}{ Average Length } \\
\hline & & Display & Referential & Display & Referential & Display & Referential \\
\hline 1. & $\begin{array}{l}\text { Teacher } \\
\text { A }\end{array}$ & $\begin{array}{l}82 \\
\text { words }\end{array}$ & $\begin{array}{l}30 \\
\text { words }\end{array}$ & 32 & 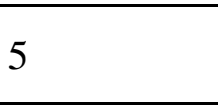 & 2.5 & 6.0 \\
\hline 2. & $\begin{array}{l}\text { Teacher } \\
\text { B }\end{array}$ & $\begin{array}{l}15 \\
\text { words }\end{array}$ & 17 words & 11 & 3 & 1.3 & 5.7 \\
\hline 3. & $\begin{array}{l}\text { Teacher } \\
\text { C }\end{array}$ & $\begin{array}{l}59 \\
\text { words }\end{array}$ & 86 words & 26 & 18 & 2.2 & 4.7 \\
\hline
\end{tabular}

The result shows display questions received shorter responses in the classroom. Ellis (1992) mentions the involvement of students' memorizing ability while describing display questions. From this, it can be inferred that display questions likely receive less response from the students than a referential question. In some cases, display questions even receive no response from the students. This condition is similar to that found in the studies conducted by Affandi, (2016) and Yunita (2016). The responses/answers given by the students tend to be short or even no answer. It is given due to the lack of comprehension, proficiency, and motivation. While answering display question type, the students' anxiety was likely rising due to the limit scope of the answer itself. Display question also likely forms as a way to recall the students' memory over the lesson they have learned. These are examples of students' answers to the display questions being asked in the classroom.

Excerpt 7 Teacher A

T: Yang mana yang artinya laut? Merujuk pada teks cerita.

(Which one means "sea" in the text?")

S: Sea

T: What happens to Malin when his mother cursed him?

S: Jadi batu. (He turned into a stone.)

Excerpt 8 Teacher B

T: Apakah bapaknya pulang ke rumah? (Is his father back home?)

S: Tidak. (No, he isn't.)

T: Apakah pekerjaan ibu Malin Kundang? (What is Malins' mother job?)

S: Jualan. (Seller)

Indonesian Journal of EFL and Linguistics, 5(2), 2020 
Naomi Dwi Aprina, Erna Andriyanti

Excerpt 9 Teacher $\mathrm{C}$

T: How is the story start and end?

S: ...

T: Impossible, is it true?

S: Yes

The answers for these questions (excerpt 7, excerpt 8 , and excerpt 9) are already known by the teacher, since the information already stated in the text. The teacher purposely asking these questions to check the students' understanding of the materials they had discussed. By looking at the students' response, these types of questions mainly received short response or even no response from the students.

On the other hand, referential questions received a long response from the students. The referential questions mostly asked about the students' opinion or evaluation of the lesson they had learned. In some cases, the teacher also asks about the students' personal experiences related to the topic they have discussed. Referred to the result of the analysis before, referential questions overall score was more than 4.7. These are examples of referential questions in the classroom along with the students' responses.

Excerpt 10 Teacher A

T: What can we get from the story?

S: Tidak boleh durhaka. (We're not supposed to be rebellious to parents.)

Harus jadi anak baik. (We should be a good child.)

Tidak boleh teriak-teriak sama orang tua. (We're not allowed to yell to parents.)

Tidak boleh bohong. (We're prohibited to lie.)

Excerpt 11 Teacher B

T: Apa saja kejelekan Malin? (What are Malins' weaknesses?)

S: Sombong (Being arrogant)

Durhaka (Having rebellious attitudes)

Pembohong (Being a liar)

Tidak menepati janji (Breaking promises)

Rakus (Being greedy) 
Teachers' Questions in Elementary School English Learning

Excerpt 12 Teacher $\mathrm{C}$

T: Bagaimana dengan keseharian kalian? (How about your daily life?)

S: Tidak menuruti orang tua (Neglecting parents' order)

Marah-marah ke orang tua (Being grumpy towards our parents)

Sombong (Being arrogant)

The answers for these questions (excerpt 10, excerpt 11, and excerpt 12) are not known by the teacher. The answer for this type of questions is different for each individual; therefore, there is no right or wrong answer. By looking at the students' response, these types of questions received long and varied response from the students. Therefore, the rate of the students' participations in the classroom practice increases.

\section{DISCUSSION}

Based on the analysis, it can be concluded that the participants use both display and referential questions in classroom practice. In the classroom of Teacher A and Teacher $\mathrm{B}$, display questions is mostly delivered by the teacher, meanwhile Teacher C equally used both display and referential questions. The higher number of display question in classroom practice is similar to several studies such as Shomoosshi (2004); Erianti., Akib., and Baso (2018); Yusriati and Tarigan (2019); Susantara \& Myartawan, (2020).

As stated previously, display questions are used for several purposes. The first is to check the students' understanding. Checking the students' understanding is essential for a learning process. This function was played in all classrooms being observed. This question was asked not only at the beginning of the lessons but also in the midst and at the end of the lessons. This type of question is seen in the excerpt 1-3 and 7-9. The teacher delivered a question to know whether a lesson was understood correctly or not by the students. Similar studies on discourse analysis (Rachmawaty \& Ariani, 2019; Yusriati \& Tarigan, 2019) pointed out the same result that checking the students' understanding through delivering questions is dominating the questioning activities in the classroom practice.

In the EFL learning the teacher used questions that mostly asked about the meaning of the target language. A question such as "which one means "sea" in the text?" is delivered to give the students" knowledge of the target knowledge. It was done to drill the students and add the amount of students' language exposure. In EFL for young learners, this method can be addressed as a way to raise the students' metacognitive awareness. According to Ellis \& Brewster (2002), young learners learn the word more toward its pronunciation and its meaning rather than the form. Furthermore, raising the students' knowledge of the words means involving the students' understanding of the words and also the capability to remember and recall the words. Therefore, it is important in young learner classroom. However, since students are varied in cognitive 
level, this kind of activity should not be applied dominantly. It is essential to avoid the boredom of high cognitive students.

Many studies on discourse analysis (Omari, 2018; Affandi, 2016; Yunita, 2016; Davies, 2011) discover that referential questions receive more variations and longer responses than the display questions. From the total responses got by the referential questions it can be inferred that referential questions can engage students more in communication/interaction. In contrast, Darong (2020) and Milawati (2017) found out that a question which requires the students to recall their knowledge give the students more opportunities to produce the language. This situation is appeared based on the teachers' consideration towards students' cognitive levels. As the student's cognitive levels are generally not really into high cognitive levels, display question types is the suitable types to be used in the classroom to avoid silent response from the students. Milawati \& Suryati (2019) mentioned that higher cognitive level questions can initiate silent response in the classroom. This finding also in-line with several studies (e.g., Wright, 2016; Shomoosshi, 2004) which conclude that students have a higher interest in producing the language when being asked about referential questions

When being asked about their opinion or personal experience, the students tend to speak more because there is no set answer to the question. Concerning the students' anxiety, receiving personal experience questions put the students in a more relaxed condition. According to Ellis \& Brewster (2002) question about the students' abilities, likes and dislikes can be used to practice the students' fluency; the language used in real communication and develops social skill. Furthermore, Davies (2011) suggested, the number of referential questions in the classroom should be added to engage the students to produce a language. To conclude, referential question is highly recommended to high cognitive levels students to increase the students' language production.

However, in some cases, the students with low comprehension of the language might encounter difficulties when receiving referential questions. As Tsui (1996) mentioned, a question which is expected to be answered longer can make the students stop producing the language. Furthermore, David (2007) discovered display question promotes interaction better than referential question in students with lower level in the classroom. This situation might be happen if the students lack the capability to nei ther use the language nor produce it. So when the teacher gives a referential question the responses are likely to be short or s/he even receives no response.

Referring to the analysis before, referential questions received more responses than display questions however the production of targeted language was very low. In EFL learning, the intensity of the target language used in the learning process is important. In the relation to questioning activity, Ratna (2017) mentioned in order to make sure the students understand teacher's questions, the teacher usually used to switch or mix the language between target language and first language, and then repeat the questions. Excerpt numbers 1, 2, 3, and 5 shows teachers mostly used Bahasa Indonesia when 
asked questions. Furthermore, the students in three classes did not speak much English when responded to the teachers' questions.

Questioning activity is an interaction initiated by a teacher. As the director of the classroom interaction, the teacher should deliver a question in the range of students' abilities. According to Marshall, Smart \& Horton (2010), there are four levels of the interactive question. Those are for beginner, intermediate, proficient and advance levels. In addition, display question type is included in beginner and intermediate levels meanwhile referential question type is a part of proficient and advance levels.

The result of the analysis shows that the cognitive level and the complexity of the questions used by the participants is varied. A question such as "what is the meaning of apologize? "is included in the beginner level while a question such as "what is Malin mothers' job?" is included in the intermediate level. The beginner level deals with how the questions challenge the students' memorizing level and is focused on one short answer. At the intermediate level, the students' understanding is checked. The typical answer at intermediate level is focused on one correct answer and sometimes open answer. From this, we can conclude that the teachers try to adjust the questions so they can cover more students' abilities.

On the other hand, referential question delivered in the classroom is categorized as proficient levels. It includes both the cognitive and complexity of the questions. The example of the questions are "What can we get from the story?, What are Malin's weaknesses, and Can you give the example of a bad attitude in your daily life?". All the questions required the students to analyze the story they have read. As referential question likely deals with interpretation, opinion, and evaluation, it is usually asked at the end of the lesson. According to Ellis \& Brewster (2002) to encourage active reflection, delivered questions should be asked clearly and relatable with the students learning experience. This activity can be done by doing the observation. The research data lead to a conclusion that the participant teachers tried to relate the questions with the students' daily life.

\section{CONCLUSION}

The teaching and learning process is an activity that includes both teacher and student's participation. The teacher should be aware of their role and their influence on the output of classroom learning. The teacher's insight into their role will help them evaluate, change, and create a better teaching environment. Furthermore, the initial success will be achieved.

Question and answer activity cannot be left out from the learning process. It is very useful for both checking and exploring the students' understanding. Even though referential questions receive more responses from the students, the teacher cannot use only this type of question all the time. The teacher should be able to recognize the right amount of referential questions and display questions in the right moment/situation. Varying the question types in each material is highly suggested. The right composition 
Naomi Dwi Aprina, Erna Andriyanti

of questioning types can be adjusted based on students' levels of ability, the purpose of the study and also students' learning strategies.

\section{REFERENCES}

Affandi, Y. (2016). Teacher's display and referential questions. NOBEL: Journal of Literature and Language Teaching, 7(1), 65-77. https://doi.org/10.15642/nobel.2016.7.1.65-77

Blackledge, A., \& Creese, A. (2009). Meaning-making as dialogic process: Official and carnival lives in the language classroom. Journal of Language, Identity, and Education, 8, 236-253.

Blosser, P.E. (1975). How to ask a right question. Washington: National Science Teacher Association.

Brown, G., \& Wragg, E.C. (2001). Questioning in the primary school. London:

Routledge.

Brown, H. D. (2001). Teaching by principle: An interactive approach to language pedagogy ( $2^{\text {nd }}$ edition). London: Longman.

Cashin, W.E. (1995, January). Answering and Asking Questions. Reprinted in IDEA PAPER NO, 31 1995,(1-8). Kansas State University

Cotton, K. (2003). Classroom Questioning: School Improvement Research Series. Portland: Northwest Regional Educational Laboratory.

Darong, H.C. (2020). Pragmatic strategy of Indonesian English teachers in questioning. JELTL (Journal of English Language Teaching and Linguistics), 5 (2), 145-162.

Darn, S. (2008). “Asking questions". in Romero, B.N.(2009). Effective teacher talk: Discourse analysis in the field of second language acquisition. GRETA, 17 (1), 18 24.

David, O.F. (2007). Teachers' questioning behavior and ESL classroom interaction pattern. Humanity and Social Science Journal, 2 (2), 127-131.

Davies, J.M. (2011). Increasing students' L2 usage: An analysis of teacher talk time and student talk time [Unpublished Manuscript]. MA TEFL/TESL Centre for English Language Studies, University of Birmingham.

Ellis, R. (1992). Second language acquisition and language pedagogy. Clevedon: Multilingual Matthes. Ltd

Erianti, A., Akib, E., \& B, F. A. (2018). An analysis of teachers' questioning strategies in ELT (English language teaching) the classroom interaction at eleventh grade SMA Muhammadiyah 1 Unismuh Makassar. Exposure Journal,7 (1), 58-69.

Fitriani, S.S. \& Amilia, K. (2017). Frequency of questions in a EFL conversation class. English Education Journal (EEJ), 8(4), 457-468.

Erlinda, R \& Dewi, S.R. (2014). Teacher's questions in EFL classroom. Ta'dib, 17(2), 177-188.

Flowerdew, J. (2013). Discourse in English language education. New York: Routledge. 
Gutierrez, K. (1993). How talk, context, and script shape contexts for learning: a cross case comparison of journal sharing. Linguistics and Education, 5 (3-4), 335-365.

Incecay, G. (2010). The role of teacher talk in young learners' language process. Social and Behaviorl Science, 2(2), 277-281.

Long, M.H., \& Sato, C.J. (1983). Classroom foreigner talk discourse: forms and functions of teachers' questions. In H.W. Seliger \& M.H. Long (Eds.). Classroom oriented research in second language acquisition. Rowley: Newbury House. pp. 268-285.

Marshall, J. C., Smart, J., \& Horton, R. M. (2010). The design and validation of EQUIP: An instrument to assess Inquiry-Based Instruction. International Journal of Science and Mathematics Education, 8(2), 299-321. https://doi.org/10.1007/s10763-009-9174-y

Milawati. (2017). Teacher questioning as a formative assessment strategy in EFL context. JELTL (Journal of English Language Teaching and Linguistics), 2(2), 117-134.

Milawati \& Suryati, N. (2019). EFL teacher's oral questioning: Are her questions and strategies effective?. Dinamika Ilmu, 19(1), 37-55.

Miles, M.B., Hubermen, A.M \& Saldana, J. (2014). Qualitative data analysis (3 ${ }^{\text {rd }}$ edition). California: Sage Publication.

Mulyati, A.F.(2013). A study of teacher talk and students talk in verbal classroom interaction to develop speaking skill for young learners. Journal of English and Education, 1(1), 1-10.

Nashruddin \& Ningtyas, P.R. (2020). English as Foreign Language (EFL) teacher's questioning strategies in classroom interaction. The journal of Ultimate Research and Trends in Education, 2 (1), 5-11.

Nunan, D. (1989). Designing tasks for the communicative classroom. Cambridge : Cambridge University Press.

Nunan, D. (1991). Language teaching methodology: A text book for teachers. Cambridge: Prentice Hall.

Nunan, D., \& Lamb. (1996). The self directed teacher. Cambridge: Cambridge University Press.

Omari, H.A. (2018). Analysis of the types of classroom questions which Jordanian English language teachers ask. Canadian Center of Science and Education, 12(4), $1-12$.

Qashoa, S.H. (2013). Effect of teacher question types and syntactic structures on EFL classroom interaction. The International Journal of Social Science, 7(1), 52-62.

Rachmawaty, N \& Ariani, S. (2019). Investigating the Types of teacher questions in EFL secondary classroom. Education and Humanities Research, 276, 40-49.

Ratna, D.H. (2017). Analyzing teacher's instructional and nonverbal communication in EFL classroom. Lingual, 9(2),1-13.

Richards, J.C. \& Lockhart, C. (1996). Reflective teaching in second language classrooms. Cambridge: Cambridge University Press. 
Romero, B.N. (2009). Effective teacher talk: Discourse analysis in the field of second language acquisition. GRETA, 17(1-2), 18-24.

Shomoosshi, N. (2004). The effect of teachers' questioning behavior on EFL classroom interaction: A classroom research study. The Reading Matrix, 2(4), 96104.

Susantara, P.A.D \& Myartawan, I.P.N.W. (2020). An analysis of teacher questions and student responses in the English teaching-learning process. Journal of Educational Research and Evaluation, 4 (3), 254-258.

Tsui, A. B. M. (1996). Reticence and anxiety in second language learning. In Bailey K. M. \& Nunan, D. (1996).Voices from the language classroom: Qualitative research in second language education. Cambridge: Cambridge University Press. pp. 145167.

Wragg, E.C. (1993). Class management. In Brown, G., \& Wragg, E.C. (2001). Questioning in the primary school. London: Routledge.

Wright, B. (2016). Display and referential questions: Effects on student responses. Nordic Journal of English Studies, 15 (4),160-189.

Yusriati \& Tarigan, D.R. (2019). An analysis of teachers' questioning strategies in english classroom: A case study at SMK Negeri 04 Medan. Presented in The 1st Multi-Discipinary International conference University Of Asahan 2019 on March 23rd, 2019. 